\title{
Mixed function oxygenases and xenobiotic detoxication/toxication systems in bivalve molluscs
}

\author{
M. N. Moore, D. R. Livingstone, P. Donkin, \\ B. L. Bayne, J. Widdows \& D. M. Lowe \\ Natural Environment Research Council, Institute for Marine Environmental Research; \\ Prospect Place, The Hoe, Plymouth PL1 3DH, England
}

\begin{abstract}
Components of a xenobiotic detoxication/toxication system involving mixed function oxygenases are present in Mytilus edulis. Our paper critically reviews the recent literature on this topic which reported the apparent absence of such a system in bivalve molluscs and attempts to reconcile this viewpoint with our own findings on NADPH neotetrazolium reductase, glucose-6phosphate dehydrogenase, aldrin epoxidation and other reports of the presence of mixed function oxygenases. New experimental data are presented which indicate that some elements of the detoxication/toxication system in $M$. edulis can be induced by aromatic hydrocarbons derived from crude oil. This includes a brief review of the results of long-term experiments in which mussels were exposed to low concentrations of the water accommodated fraction of North Sea crude oil $\left(7.7-68 \mu \mathrm{g} \mathrm{l}^{-1}\right)$ in which general stress responses such as reduced physiological scope for growth, cytotoxic damage to lysosomal integrity and cellular damage are considered as characteristics of the general stress syndrome induced by the toxic action of the xenobiotics. In addition, induction in the blood cells of microsomal NADPH neotetrazolium Ieductase (associated with mixed function oxygenases) and the NADPH generating enzyme glucose-6-phosphate dehydrogenase are considered to be specific biological responses to the presence of aromatic hydrocarbons. The consequences of this detoxication/toxication system for Mytilus edulis are discussed in terms of the formation of toxic electrophilic intermediate metabolites which are highly reactive and can combine with DNA, RNA and proteins with subsequent damage to these cellular constituents. Implications for neoplasms associated with the blood cells are also discussed. Finally, in view of the increased use of mussel species in pollutant monitoring programmes, the induction phenomenon which is associated with microsomal enzymes in the blood cells is considered as a possible tool for the detection of the biological effects of environmental contamination by low concentrations of certain groups of organic xenobiotics.
\end{abstract}

\section{INTRODUCTION}

Cytochrome P-450-dependent mixed function oxygenases (monooxygenases) are involved in the transformation, to polar metabolites, of a wide range of organic compounds including many foreign non-biological compounds or xenobiotics (Krieger \& Wilkinson, 1969; Conney \& Burns, 1972; Bend et al., 1977). These enzymes are frequently associated with the endoplasmic reticulum (microsomes) and the membranes of the nuclear envelope (Khandwala \& Kaspar, 1973); they require NADPH and oxygen. 
This system can function as a mechanism for the detoxication of organic environmental contaminants; however, in the course of such transformations reactive electrophilic metabolites can be formed (Kuroki et al., 1971-72; Daly et al., 1972; Jerina \& Daly, 1974; Jollow et al., 1974; Sims \& Grover, 1974), some of which are carcinogens, mutagens or other cytotoxic agents. The mixed function oxygenases must therefore be viewed as components of a detoxication/toxication system, as some of the metabolites may be more biologically damaging than the parent compound.

A number of previous investigators have argued that bivalve molluscs do not have the capability to metabolise organic xenobiotics (Carlson, 1972; Lee et al., 1972; Payne, 1977; Vandermeulen \& Penrose, 1978) and this argument has been used as a partial explanation for the persistence of hydrocarbons within the tissues of bivalves exposed to contamination (Lee et al., 1972). However, recent evidence suggests that xenobiotic detoxication systems are present in bivalves although the levels of activity are low in comparison with fish and mammals. Bend et al. (1977) have demonstrated the presence of epoxide hydrase in the digestive gland of the blue mussel, Mytilus edulis, while the epoxidation of aldrin to dieldrin by a mixed function oxygenase has been reported in Anodonta sp. (Khan et al., 1972), in Mytilus californianus (Gee et al., 1979; Krieger et al., 1979) and in $M$. edulis (Bayne et al., 1979; Widdows et al., 1980a). Trautman et al. (1979) have also reported the presence of mixed function oxygenase-mediated $o$-demethylation of $p$-nitroanisole in whole-body microsomal preparations from $M$. californianus, while Krieger et al. (1979) have shown that this mussel can also hydroxylate antipyrine (2,3dimethyl-1-phenyl-2-pyrazolin-5-one) in vivo. The hydroxylation of benzo(a)pyrene by a mixed function oxygenase has also been reported to occur in M. edulis (Stegeman, 1980); Payne, personal communication).

Evidence of an association of the detoxication system with particular tissues and cells in $M$. edulis has been indicated from cytochemical investigations of the distribution of NADPH neotetrazolium reductase (Bayne et al., 1979; Moore, 1979, 1980; Widdows et al., 1980a), which appears to represent the oxidation of NADPH by the microsomal respiratory chain terminating in the mixed function oxygenase (Koudstaal \& Hardonk, 1969, 1972; Richards, 1973; Hardonk \& Koudstaal, 1976; Chayen, 1978; Lindner \& Beyhl, 1978). Previous results show that NADPH neotetrazolium reductase is particularly active in the blood cells (haemocytes) of $M$. edulis, although there is also some activity associated with both the intestinal epithelium and developing oocytes (Moore, 1979). This evidence of comparatively high activity in the blood cells is complemented by correspondingly high levels of mixed function oxygenase (aldrin epoxidation) in these cells (Widdows et al., 1980a).

The occurrence of enzymic-induction of some components of the microsomal detoxication system (see review by Conney \& Burns, 1972) is evident from investigations of the effects of phenobarbital, anthracene, phenanthrene, 2,3-dimethylnaphthalene and the water accomodated fraction (WAF) of crude oil which all cause a stimulation of NADPH neotetrazolium reductase activity (Bayne et al., 1979; Moore, 1979, 1980), as well as the NADPH generating enzymes (WAF only tested) glucose-6-phosphate dehydrogenase and isocitrate dehydrogenase (Bayne et al., 1979).

As stated above, the detoxication system can facilitate the formation of reactive intermediate metabolites which have a potential for damage to cellular macromolecules including DNA (Gillette et al., 1978; Lesko et al., 1978). In this context neoplastic blood 
cells have been reported from a number of bivalves including $M$. edulis (Farley, 1969a, b; Farley \& Sparks, 1970; Barry \& Yevich, 1972; Mix, 1975; Mix et al., 1977) while Lowe \& Moore (1978) have demonstrated that neoplastic mussels, from a population near Plymouth, were naturally exposed to a range of polycyclic aromatic hydrocarbons. However, the evidence for any association between the presence of the detoxication/ toxication system in the blood cells and the occurrence of haemocytic neoplasia is purely circumstantial and without experimental induction of this latter condition must remain speculative.

In this paper we report on experimentally induced effects of the WAF of North Sea crude oil and 2,3-dimethylnaphthalene on mixed function oxygenase, NADPH neotetrazolium reductase and NADPH generating enzymes in $M$. edulis.

\section{MATERIALS AND METHODS}

\section{Experimental treatment of mussels with hydrocarbons}

Mussels (Mytilus edulis), 50-60 $\mathrm{mm}$ in shell length, were collected from the estuary of the River Erme (Devon) and held at the seasonal ambient temperature in a system of recirculating seawater. All mussels were fed an algal diet of Phaeodactylum tricornutum and Isochrysis galbana at a concentration of 4000-6000 cells ml-1.

Mussels were continuously exposed in a flow-through system to low concentrations of the water accommodated fraction (WAF) of North Sea Crude Oil. In this paper we present results form three experiments: Experiment I: November 1977, $12 \mu \mathrm{g}$ total hydrocarbons $1^{-1}$ ( \pm 2.2 S.E.); Experiment II: April 1978, $7.7 \mu \mathrm{g} \mathrm{l}^{-1}$ ( \pm 0.7 S.E.) and $68 \mu \mathrm{g}$ $\mathrm{l}^{-1}$ ( \pm 9 S.E.); Experiment III: October 1978-April 1979, $30 \mu \mathrm{g} \mathrm{l}^{-1}$ ( \pm 4.5 S.E.). A stock of water accomodated hydrocarbon $\left(4.2 \mathrm{mg} \mathrm{l}^{-1}\right)$ was prepared daily, by gently mixing 201 of seawater and $250 \mathrm{ml}$ of crude oil on a magnetic stirrer for a period of $18 \mathrm{~h}$ and then leaving undisturbed for a further $6 \mathrm{~h}$.

In Experiment $\mathrm{I}$, the method of dosing and diluting the stock WAF differed from that of Experiments II and III. Experiment I achieved an exposure concentration of $12 \mu \mathrm{g} \mathrm{I}^{-1}$ by pumping $20 \mathrm{l}$ of stock per day into the seawater aquarium (volume $3000 \mathrm{l}$ ). During this experiment the seawater was neither aerated nor filtered. In Experiments II and III the stock WAF was pumped $\left(13 \mathrm{ml} \mathrm{min} \mathrm{m}^{-1}\right)$ into the stream of inflowing seawater before entering the tank containing the experimental animals. The required exposure concentration was therefore determined by the flow rate of incoming seawater. Under these experimental conditions the hydrocarbon levels in the total seawater system were maintained at background concentrations by means of aeration and filtration. Control animals were held in a separate system of recirculating seawater.

The hydrocarbon concentrations in the stock, experimental and control tanks were monitored twice a week. Following extraction into hexane, either by means of shaking or steam distillation, the hydrocarbons were measured in terms of naphthalene equivalents at $220 \mathrm{~nm}$. Additional water samples were analysed by gas chromatography in order to derive a conversion factor from naphthalene equivalents to total hydrocarbons.

In a further series of experiments mussels were injected with either WAF $\left(7.6 \mathrm{mg} \mathrm{l}^{-1}\right)$ as prepared above or with 2,3-dimethylnaphthalene (July, 1979). Injections (100 $\mu \mathrm{l} /$ 
mussel) were made into the posterior adductor muscle using a 26-gauge hypodermic needle for WAF together with a millipore-filtered seawater (MFSW) vehicle control, and a 23-gauge needle for 2,3-dimethylnaphthalene $\left(10^{-2} \mathrm{M}\right)$ dissolved in medicinal liquid paraffin with a liquid paraffin vehicle control. Tissues were sampled for enzyme assays after $24 \mathrm{~h}$ at $15^{\circ} \mathrm{C}$, the seasonal ambient temperature.

\section{Assay for mixed function oxygenase}

Blood (between 0.5 and $2 \mathrm{ml}$ per mussel) was removed from the posterior adductor muscle by means of a syringe and bulked, to a total volume of $30 \mathrm{ml}$, in a polycarbonate centrifuge tube. Blood cells were sedimented by centrifugation at $500 \mathrm{~g}$ for $10 \mathrm{~min}$ then transferred to a glass Potter-Elvehjem homogeniser vessel in a total volume of $6 \mathrm{ml}$ of 0.1 M HEPES (N-2-hydroxy-ethylpiperazine- $\mathrm{N}^{\prime}$-2-ethanesulphonic acid) ( $\mathrm{pH} 7.6$ ) buffer containing $\mathrm{NaCl}(3 \%, 0.514 \mathrm{M})$ and $10 \mathrm{mM} \mathrm{MgSO}_{4}$. After addition of an ethanol solution of phenylmethylsulphonylfluoride (PMSF) ( $2 \mu \mathrm{l}$ of solution $\mathrm{ml}^{-1}$ buffer to a final PMSF concentration of $0.1 \mathrm{mM}$ ) the cells were homogenised by 10 passes of a motor-driven teflon pestle.

Mantle tissue and digestive glands were dissected from mussels not previously used for blood sampling and homogenised essentially as for blood, but using $20 \mathrm{ml}$ of buffer $\mathrm{g}^{-1}$ wet weight of tissue. For each experimental treatment, either 5 or 6 animals were assayed individually. Homogenates were centrifuged at $10,000 \mathrm{~g}$ for $30 \mathrm{~min}$ and clear supernatant was removed for assay. Blood, dissected tissue and homogenates were maintained at or below $4{ }^{\circ} \mathrm{C}$ throughout.

Aldrin epoxidase activity was determined in incubations of the following composition: $0.1 \mathrm{M}$ HEPES buffer (pH 7.6); $\mathrm{MgSO}_{4}, 10 \mathrm{mM} ; \mathrm{NaCl}, 0.51 \mathrm{M}_{i} \mathrm{NADPH} 0.3 \mathrm{mM}$; glucose-6-phosphate, $1.8 \mathrm{mM}$; tissue homogenate $0.8 \mathrm{ml}$ (digestive gland and mantle) or $3.8 \mathrm{ml}$ (blood) and aldrin, $0.23 \mu \mathrm{mole}$, added in $10 \mu \mathrm{l}$ of methanol. Total volumes were adjusted to $4 \mathrm{ml}$ with buffer and the incubations carried out aerobically at $25^{\circ} \mathrm{C}$ for $1 \mathrm{~h}$ with frequent shaking. Blanks were run without cofactors, with homogenate replaced by buffer, and with all components but stopped at zero time.

The incubations were stopped by extraction with $4 \mathrm{ml}$ of $15 \%(\mathrm{v} / \mathrm{v})$ diethyl ether in hexane followed by cooling. Extraction was completed with a further two 4-ml volumes of ether/hexane, the bulked extracts concentrated to $2 \mathrm{ml}$ and analysed for dieldrin by electron capture detector gas chromatography.

Homogenate protein concentrations were assayed by the method of Lowry et al. (1951) relative to a bovine serum albumen (fraction V) standard calibration curve prepared with appropriate dilutions of homogenising buffer.

\section{Quantitative cytochemical assay for NADPH neotetrazolium reductase}

A small piece (approx. $5 \mathrm{~mm}^{3}$ ) of the visceral mass from experimental mussels was rapidly excised, frozen in hexane $\left(-70^{\circ} \mathrm{C}\right)$ and sectioned $(10 \mu \mathrm{m})$ in a Bright Cryostat at a cabinet temperature of -25 to $-30^{\circ} \mathrm{C}$ with a dry-ice cooled knife. NADPH neotetrazolium reductase was demonstrated in unfixed sections using a modification of the method described by Altman (1972) which employed $100 \mathrm{mM}$ HEPES buffer ( $\mathrm{pH} 8.0$ ) containing $20 \mathrm{mM} \mathrm{MgCl} 2,20 \%$ PVA and $5 \mathrm{mM}$ neotetrazolium chloride (Sigma). Incubation was for 
$30 \mathrm{~min}$ in a nitrogen atmosphere at $37^{\circ} \mathrm{C}$. Control sections omitted NADPH from the incubation medium. Microdensitometric measurements were made on individual blood cells in sections stained for NADPH neotetrazolium reductase (10 readings/section) using a Vickers M 85 scanning integrating microdensitometer at a wavelength of $585 \mathrm{~nm}$ (Butcher and Altman, 1973; slit width setting $=60$; measuring spot $=0.5 \mu \mathrm{m}$ diameter). The data were analysed using the Mann-Whitney U-test between control and experimental groups and a probability value of less than 0.05 was accepted as significant.

\section{Assays for glucose-6-phosphate dehydrogenase}

On each sampling occasion, individual mussels were taken and a sample of blood removed from the posterior adductor muscle by hypodermic syringe. The digestive gland was excised, damp-dried, weighed and placed on ice. All procedures were carried out at $4{ }^{\circ} \mathrm{C}$. The blood samples were centrifuged at $1000 \mathrm{~g}$ for $10 \mathrm{~min}$ and the blood cells resuspended in the same volume of sterilised seawater. After a second spin, the blood cells were resuspended in the same volume of $10 \mathrm{mM}$ tris- $\mathrm{HCl} \mathrm{pH} 7.7$ containing $1 \mathrm{mM}$ EDTA (ethylenediamine tetra-acetic acid) and $1 \mathrm{mM} \mathrm{DTT}$ (dithiothreitol) and sonicated for three 5-s periods using a MSE sonicator operating at an amplitude of $18 \mu \mathrm{m}$. The sonicated samples were assayed for glucose-6-phosphate dehydrogenase (E.C. 1.1.1.49G6PDH) as described in Bayne et al. (1979), and for protein either by the direct spectrophotometric method of Groves et al. (1968), or by the method of Lowry et al. (1951).

Excised digestive glands were gently homogenised in approximately 15 volumes (W : V) of $0.8 \mathrm{M}$ sucrose containing $10 \mathrm{mM}$ tris- $\mathrm{HCl} \mathrm{pH} 7.7,1 \mathrm{mM}$ EDTA and $1 \mathrm{mM}$ DTT using an ultra-turrax homogeniser. The homogenates were centrifuged at $40,000 \mathrm{~g}$ for 30 min and the resulting supernatants assayed for G6PDH as above. In later experiments (see Table 7), this supernatant was further centrifuged at $100,000 \mathrm{~g}$ for $90 \mathrm{~min}$ to yield a high-spin supernatant (cytosolic G6PDH) and a microsomal pellet which was resuspended in a minimum volume of homogenising buffer (sucrose omitted) (microsomal G6PDH). The data were analysed by one-way analysis of variance between two groups of values or for several group values over time. A probability value of less than 0.1 was accepted as significant.

\section{RESULTS AND DISCUSSION}

\section{Mixed function oxygenase}

Aldrin epoxidation has been demonstrated in 10,000 g supernatants (generally denoted "post mitochondrial" supernatant, PMS) from three tissues of $M$. edulis (Table 1). Dieldrin production per incubation increased linearly as PMS concentration was increased up to $0.8 \mathrm{mg}$ of protein $\mathrm{ml}^{-1}$ of incubate, and activity was totally destroyed by heat $\left(100^{\circ} \mathrm{C}\right.$ for $\left.3 \mathrm{~min}\right)$ indicating an enzymic mechanism. Omission of NADPH generally reduced epoxidase activity to the level of the blanks, though occasionally up to $20 \%$ of the activity of the complete system was present, probably mediated by endogenous cofactors. This NADPH requirement provides evidence for a mixed function oxygenase mechanism for the metabolism of aldrin. 
Table 1. Epoxidation of aldrin by $10,000 \mathrm{~g}$ supernatants derived from $M$. edulis tissues *

\begin{tabular}{|c|c|c|}
\hline & Tissue & $\begin{array}{l}\text { Rate of dieldrin formation } \\
\left(\text { pmole }^{-1} \mathrm{mg}_{\text {protein }}^{-1} \text { ) }\right. \\
\text { Mean } \pm \mathrm{SE}_{\mathrm{t}} \mathrm{n}=6\end{array}$ \\
\hline & $\begin{array}{l}\text { Mantle } \\
\text { Digestive gland } \\
\text { Blood cells** }\end{array}$ & $\begin{aligned} 27.7 & \pm 5.7 \\
2.0 & \pm 0.5 \\
54.9 & \end{aligned}$ \\
\hline \multicolumn{3}{|c|}{$\begin{array}{l}\text { * Mussels sampled during May } 1978 \\
\text { ** Single incubation; blood pooled from } 30 \text { animals }\end{array}$} \\
\hline
\end{tabular}

Rates of aldrin epoxidation in mantle tissue (wet weight basis; Table 2) were similar to those reported by Khan et al. (1972) for digestive gland of the freshwater mussel Anodonta sp. (3.07 $\mathrm{nmole}^{-1} \mathrm{~g}^{-1}$ ) and by Willis \& Addison (1974) for biphenyl hydroxylation by homogenates of whole $M$. edulis $\left(6.3 \pm 4.6\right.$ S.D. $\left.\mathrm{nmole}^{-1} \mathrm{~g}^{-1}\right)$. Expressed on a wet weight basis, the mean rate for the results for mantle tissue given in Table 1 was 1.67 \pm 0.23 (mean $\pm \mathrm{SE}, \mathrm{n}=6$ ) $\mathrm{nmole}^{-1} \mathrm{~g}^{-1}$. Expressed on a protein basis (as in Table 1) this rate was below that reported for aldrin epoxidation $\left(60-300 \mathrm{pmole} \mathrm{h}^{-1} \mathrm{mg}^{-1}\right)$ by Krieger et al. (1979) in various tissues of Mytilus californianus; comparable rates for rat liver were $6,000 \mathrm{pmole} \mathrm{h}^{-1} \mathrm{mg}^{-1}$ (Krieger et al., 1979). At the time of the assay presented in Table 1 (May), epoxidation rates in mantle were greater than in digestive gland, although the results for digestive gland must be interpreted with caution (see below). Blood cells showed the highest activity and if these rates were compared using an estimated blood cell wet weight (see Widdows et al., 1980a), blood cells were scored as the most active tissue. Further studies (Donkin, unpublished data) have shown that although blood cell epoxidase activity can be high, this is not the case for all groups of animals tested. The reason for this variability is not yet clear.

Despite reports that aldrin epoxidase activity is inducible in fish by petroleum pollution (Burns, 1976) and 3-methylcholanthrene (Addison et al., 1978), injection of WAF or 2,3-dimethylnaphthalene failed significantly to increase epoxidase activity in mantles of $M$. edulis (Table 2). Variability was considerable, however, due possibly to the samples being a mixture of pre- and post-spawning specimens of both sexes.

Table 2. Epoxidation of aldrin by $10,000 \mathrm{~g}$ mantle tissue * supernatants derived from $M$. edulis injected with WAF and 2,3-dimethylnaphthalene sampled $24 \mathrm{~h}$ after injection

\begin{tabular}{|c|c|c|}
\hline \multirow[t]{2}{*}{ Treatment } & \multicolumn{2}{|c|}{$\begin{array}{l}\text { Rate of dieldrin formation } \\
\left(\text { nmole } \mathrm{h}^{-1} \mathrm{~g} \text { wet wt. }{ }^{-1} \text { ) }\right. \\
\text { Mean } \pm \mathrm{SE}, \mathrm{n}=5\end{array}$} \\
\hline & Control & Experimental \\
\hline Injection of $100 \mu \mathrm{l}$ of WAF $\left(7.63 \mathrm{mg} \mathrm{l}^{-1}\right)$ & $2.77 \pm 0.45$ & $2.88 \pm 0.38$ \\
\hline Injection of $100 \mu \mathrm{l}$ of 2,3 -dimethylnaphthalene $\left(10^{-2} \mathrm{M}\right)$ & $2.40 \pm 0.59$ & $2.56 \pm 1.00$ \\
\hline
\end{tabular}


Table 3. Responses of NADPH neotetrazolium reductase activity in the blood cells of $M$. edulis exposed to WAF of North Sea crude oil

\begin{tabular}{|c|c|c|c|}
\hline \multirow[t]{2}{*}{ Experiment } & \multirow[t]{2}{*}{$\begin{array}{c}\text { Time } \\
\text { (days) }\end{array}$} & \multicolumn{2}{|c|}{$\begin{array}{l}\text { Relative absorbance of NADPH } \\
\text { neotetrazolium reductase activity } \\
\text { (machine units of absorbance) } \\
\text { Mean } \pm \mathrm{SE}, \mathrm{n}=5\end{array}$} \\
\hline & & Control & Experimental \\
\hline \multirow[t]{6}{*}{$\mathrm{I}\left(12 \mu \mathrm{g} \mathrm{l}^{-1}\right)$} & 7 & $18.23 \pm 2.00^{*}$ & $33.84 \pm 3.05$ \\
\hline & & $16.21 \pm 2.13^{*}$ & $33.09 \pm 2.37$ \\
\hline & 14 & & $32.06 \pm 3.23$ \\
\hline & & & $30.32 \pm 3.07$ \\
\hline & 35 & $21.30 \pm 1.94$ & $35.63 \pm 2.29$ \\
\hline & & $23.94 \pm 2.19$ & $42.18 \pm 3.91$ \\
\hline II $\left(7.7 \mu \mathrm{g} \mathrm{I}^{-1}\right)$ & 3 & $12.79 \pm 1.56$ & $20.80 \pm 2.50$ \\
\hline $\mathrm{II}\left(68 \mu \mathrm{g} \mathrm{l}^{-1}\right)$ & 3 & & $28.41 \pm 2.82$ \\
\hline * Duplicate sample & & & \\
\hline
\end{tabular}

Digestive glands gave even more variable results. Animals injected with 2,3-dimethylnaphthalene showed no activity whereas those injected with WAF formed dieldrin at the rate of $0.96 \pm 0.44$ compared to control $0.19 \pm 0.03$ (mean $\pm S E, n=4$; nmole $h^{-1} \mathrm{~g}^{-1}$ ). These results were of limited value, however, since digestive gland PMS contained constituents which, even when diluted 20 times, could completely inhibit mantle activity. Krieger et al. (1979) also refer to variable levels of inhibitors in $M$. californianus viscera.

The presence of epoxidase activity in blood cells further complicates the interpretation of results from the mantle and digestive gland, since numbers of blood cells in these tissues are variable (Lowe \& Moore, unpublished observations).

\section{NADPH neotetrazolium reductase}

NADPH neotetrazolium reductase was principally localised in the blood cells of Mytilus as found in previous experiments (Bayne et al., 1979; Moore, 1979). Microdensitometrically determined activity from individual blood cells showed that there was a significant increase after 7,14 and 35 days of exposure to water accommodated fraction (Experiment $I$, Table 3). This induction was consistent in replicate samples and constituted almost a doubling of activity in blood cells from control mussels (Table 3). These results have received further confirmation from evidence of similar induction of this enzyme in several other experiments with water accommodated fraction (see Experiment II, Table 3).

Injection of experimental mussels with WAF resulted in significant induction of $\mathrm{NADPH}$ neotetrazolium reductase after $24 \mathrm{~h}$ (2 replicate experiments; Table 4). Similar injections of 2,3-dimethylnaphthalene also stimulated an increase in activity after $24 \mathrm{~h}$ (Table 4).

A previous experiment in which 2,3-dimethylnaphthalene was injected showed a 
Table 4. Responses of NADPH neotetrazolium reductase activity in the blood cells of $M$. edulis injected with WAF and 2,3-dimethylnaphthalene; sampled $24 \mathrm{~h}$ after injection

\begin{tabular}{|c|c|c|}
\hline \multirow[t]{2}{*}{ Treatment } & \multicolumn{2}{|c|}{$\begin{array}{l}\text { Relative absorbance of NADPH } \\
\text { neotetrazolium reductase activity } \\
\text { (machine units of absorbance) } \\
\text { Mean } \pm \mathrm{SE}_{\mathrm{r}} \mathrm{n}=5\end{array}$} \\
\hline & COINOL & Lxpentuletal \\
\hline Injection of $100 \mu \mathrm{l}$ of WAF $\left(7.63 \mathrm{mg} \mathrm{l}^{-1}\right)$ & $\begin{array}{l}19.62 \pm 1.23^{*} \\
18.39 \pm 0.49^{*}\end{array}$ & $\begin{array}{l}24.62 \pm 0.48 \\
24.32 \pm 0.84\end{array}$ \\
\hline Injection of $100 \mu \mathrm{l}$ of 2,3 -dimethylnaphthalene $\left(10^{-2} \mathrm{M}\right)$ & $17.81 \pm 0.49$ & $23.53 \pm 0.76$ \\
\hline Results from duplicate experiments & & \\
\hline
\end{tabular}

much greater stimulation of NADPH neotetrazolium reductase (Moore, 1979). However, this experiment was carried out during the late winter (February-March) before the spawning period, while the results described above were obtained after spawning and during the sexual resting stage. The mixed function oxygenase system is involved in steroid metabolism (see review by Conney \& Burns, 1972) and this seasonal variation in the induction response of NADPH neotetrazolium reductase in $M$. edulis may be influenced by the reproductive cycle and its hormonal control.

\section{Glucose-6-phosphate dehydrogenase}

An increase in G6PDH activity of the combined gill and kidney tissues with exposure of $M$. edulis to WAF was detected in earlier experiments, although individual variability was high (see Bayne et al., 1979). However, following the identification of the blood cells as being particularly active for NADPH neotetrazolium reductase (Bayne et al., 1979, Moore, 1979, 1980); investigations were concentrated on the blood cells and on the digestive gland (a tissue rich in blood cells - see Moore, 1979).

The specific activity of blood cell G6PDH was higher than the control levels during the first three days of exposure of mussels to WAF (Table 5). It was significantly higher $24 \mathrm{~h}$ after the injection of 2,3-dimethylnaphthalene but not after the injection of WAF (Table 5). Total blood cell G6PDH activity, which reflects the number of blood cells present in the haemolymph, showed considerable variability between experiments and between individual mussels (Table 5). This variability probably arises because the blood cells migrate into and out of the tissues and at any moment in time a large and variable fraction may be present in the tissues and absent from the haemolymph (Lowe \& Moore, unpublished observations). However, considering the pooled data for the first three days of exposure of mussels to WAF, an increase in total blood cell G6PDH activity was observed. Digestive gland G6PDH ("post-40,000 g supernatant" - combined cytosolic and microsomal activity) did not increase with the exposure of mussels to WAF except in one experiment with long-term exposure (see Experiment III, Table 6). Control values varied with the time of the year (Table 6) reflecting the known seasonal pattern of change in G6PDH activity (Silva-Pando et al., 1978; Head, 1979; Livingstone, 1980). In contrast to the exposure experiments, both cytosolic and microsomal G6PDH increased 
Table 5. Responses of glucose-6-phosphate dehydrogenase activity in the blood cells of $M$. edulis to WAF of North Sea crude oil and 2,3-dimethylnaphthalene

\begin{tabular}{|c|c|c|c|c|c|}
\hline \multirow[t]{2}{*}{ Treatment } & \multirow{2}{*}{$\begin{array}{l}\text { Time } \\
\text { (days) }\end{array}$} & \multicolumn{2}{|c|}{ Specific activity* } & \multicolumn{2}{|c|}{ Total activity ${ }^{* *}$} \\
\hline & & Control & Experimental & Control & Experimental \\
\hline \multirow[t]{4}{*}{$\begin{array}{l}\text { Exposure to WAF }\left(68 \mu \mathrm{gl}^{-1}\right) \\
\text { (Experiment II) }^{+}\end{array}$} & 0.25 & $0.099 \underset{(8)^{* * *}}{ \pm 0.014}$ & $0.126 \pm 0.017$ & $6.81 \pm 1.46$ & $8.30 \pm 1.28$ \\
\hline & 1.25 & $0.059 \pm 0.012$ & $0.128 \pm 0.023$ & $4.32 \pm 0.73$ & $9.87 \pm 1.85$ \\
\hline & 3 & $0.090 \pm 0.012$ & $0.164 \pm 0.041$ & $8.71 \pm 2.96$ & $12.33 \pm 3.75$ \\
\hline & 7 & $\begin{array}{c}0.126 \pm 0.019 \\
(8)\end{array}$ & $0.126 \pm 0.016$ & $6.04 \pm 1.67$ & $7.02 \pm 1.02$ \\
\hline $\begin{array}{l}\text { Injection of } 100 \mu \mathrm{l} \text { of WAF } \\
\left(7.63 \mathrm{mg} \mathrm{l}^{-1}\right)^{++}\end{array}$ & 1 & $0.047 \pm \underset{(6)}{ \pm} 0.009$ & $0.097 \pm 0.029$ & $12.36 \pm 3.86$ & $13.59 \pm 3.12$ \\
\hline $\begin{array}{l}\text { Injection of } 100 \mu \mathrm{l} \text { of } \\
2,3-\text { dimethylnaphthalene } \\
\left(10^{-2} \mathrm{M}\right)^{++}\end{array}$ & 1 & $\begin{array}{c}0.058 \pm 0.012 \\
(11)\end{array}$ & $\begin{array}{c}0.102 \pm 0.017 \\
(11)\end{array}$ & $20.74 \pm 4.98$ & $20.69 \pm 3.84$ \\
\hline \multicolumn{6}{|c|}{${ }^{*} \quad \mu$ moles $\min ^{-1}$ mg protein ${ }^{-1}($ mean $\pm \mathrm{SE})$} \\
\hline \multicolumn{6}{|c|}{$*$ nmoles $\min ^{-1} \mathrm{ml}$ blood ${ }^{-1}($ mean $\pm S E)$} \\
\hline \multicolumn{6}{|c|}{ *** Number of individuals per sample } \\
\hline \multirow{2}{*}{\multicolumn{6}{|c|}{$+\quad$ Protein measured by the method of Groves et al. (1968) }} \\
\hline++ Protein measured by $t$ & & & et al. (1951) & & \\
\hline
\end{tabular}

Table 6. Responses of glucose-6-phosphate dehydrogenase activity of the digestive gland of $M$. edulis exposed to WAF of North Sea crude oil

\begin{tabular}{|c|c|c|c|}
\hline \multirow[t]{2}{*}{ Experiment } & \multirow[t]{2}{*}{$\begin{array}{l}\text { Length of } \\
\text { exposure } \\
\text { (days) }\end{array}$} & \multicolumn{2}{|c|}{$\begin{array}{l}\text { Specific activity } \\
\left(\mu \text { moles } \min ^{-1} \mathrm{~g} \text { wet } \mathrm{wt}^{-1}\right) \\
\text { Mean } \pm \text { S.E. }\end{array}$} \\
\hline & & Control & Experimental \\
\hline \multirow[t]{2}{*}{$\mathrm{I}\left(12 \mu \mathrm{g} \mathrm{I}^{-1} ;\right.$ Nov. 1977$)$} & 7 & $\begin{array}{c}2.13 \pm 0.47 \\
(4)^{* *}\end{array}$ & $1.40 \pm 0.11$ \\
\hline & 22 & $\begin{array}{c}2.10 \pm 0.19 \\
(4)\end{array}$ & $\begin{array}{c}1.70 \pm 0.15 \\
(4)\end{array}$ \\
\hline \multirow[t]{4}{*}{ II $\left(68 \mu \mathrm{g} \mathrm{I}^{-1}\right.$ Apr. 1978) } & 0.25 & $\begin{array}{c}1.89 \pm 0.21 \\
(8)\end{array}$ & $\begin{array}{c}1.78 \pm 0.17 \\
(8)\end{array}$ \\
\hline & 1.25 & $\begin{array}{c}1.25 \pm 0.16 \\
(8)\end{array}$ & $\begin{array}{c}1.02 \pm 0.17 \\
(8)\end{array}$ \\
\hline & 3 & $\begin{array}{c}2.03 \pm 0.10 \\
(8)\end{array}$ & $\begin{array}{c}1.87 \pm 0.11 \\
(8)\end{array}$ \\
\hline & 7 & $\begin{array}{c}1.75 \pm 0.19 \\
(8)\end{array}$ & $1.65 \pm 0.18$ \\
\hline III $\left(30 \mu \mathrm{g} \mathrm{l}^{-1}\right.$; Feb. 1979) & 210 & $\begin{array}{c}1.16 \pm 0.06 \\
(6)\end{array}$ & $\begin{array}{c}1.41 \pm 0.09 \\
(6)\end{array}$ \\
\hline \multicolumn{4}{|c|}{$\begin{array}{l}\text { G6PDH activity was measured in post- } 40,000 \mathrm{~g} \text { supernatant and represents the sum of } \\
\text { cytosolic and microsomal activities } \\
\text { ** Number of individuals per sample }\end{array}$} \\
\hline
\end{tabular}


Table 7. Responses of cytosolic and microsomal glucose-6-phosphate dehydrogenase activity of the digestive gland of $M$. edulis injected with WAF and 2,3-dimethylnaphthalene; sampled $24 \mathrm{~h}$ after injections

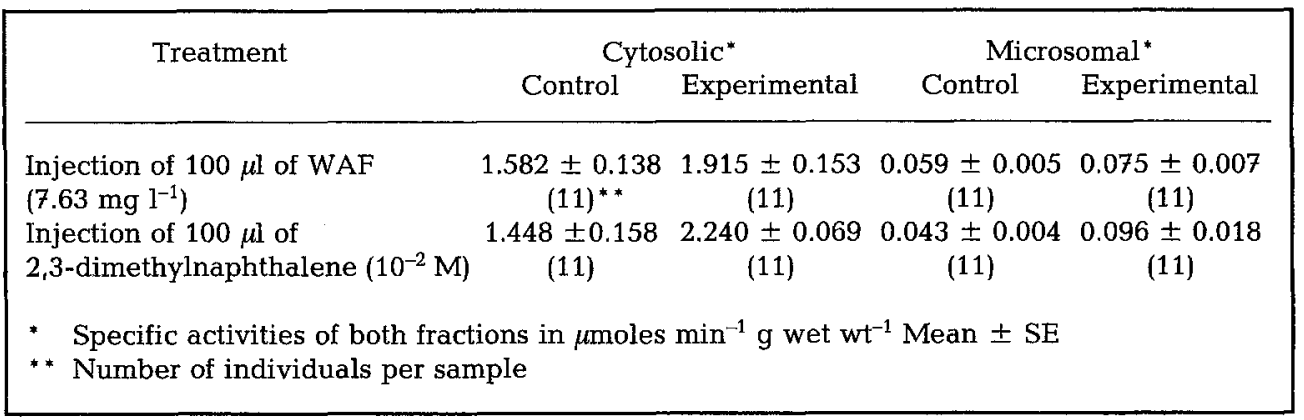

in activity following an injection of 2,3-dimethylnaphthalene while a similar, but reduced, effect was seen for the microsomal G6PDH following an injection of WAF (Table 7).

It is well established for mammalian tissues that treatment with such compounds as phenobarbital leads to an increase in G6PDH activity (Altman, 1972). The results are less definitive for the effects of polycyclic hydrocarbons with both increases (Koudstaal \& Hardonk, 1972) and no change (Bresnick \& Yang, 1964) in G6PDH activity being recorded. These differences have probably arisen because the different techniques used either measure cytosolic or microsomal activities or both, and it is now realised that the two G6PDH's are genetically distinct enzymes, at least in vertebrates, with different properties (see Stegeman \& Klotz, 1979). Cytosolic G6PDH functions efficiently only with glucose-6-phosphate as substrate, while the microsomal G6PDH will also utilise galactose-6-phosphate and glucose and is probably identical with the enzyme formerly known as glucose dehydrogenase (E.C. 1.1.1.47) (see Hori \& Takahashi, 1974). The microsomal enzyme has been retermed hexose-6-phosphate dehydrogenase and has been suggested as being important in providing reducing equivalents for the mixedfunction oxygenase reactions (Kimura et al., 1979; Stegeman \& Klotz, 1979). By contrast, the cytosolic G6PDH has a major role in the pentose phosphate pathway. The results with $M$. edulis, therefore, indicate that changes in G6PDH activities are part of the response to aromatic hydrocarbons but research is required to resolve the functions of the two enzymes, particularly in the context of seasonal variations in activity and sex differences (see Livingstone, 1980).

\section{Induction of the detoxication system as a specific response to organic xenobiotics}

The stimulation of activity of mixed function oxygenases and associated microsomal enzymes by a wide variety of organic compounds has been recognised in mammals and fish for many years (see review by Conney \& Burns, 1972; Payne \& Penrose, 1975; Stegeman \& Sabo, 1976; Bend et al., 1977). Although we have no definitive evidence of induction of mixed function oxygenases in bivalves, there is clearly an enhancement of NADPH neotetrazolium reductase, glucose-6-phosphate dehydrogenase and microso- 
mal hexose-6-phosphate dehydrogenase following experimental treatment with injected aromatic hydrocarbons and environmentally realistic levels of WAF. Accordingly, induction of these systems in $M$. edulis and possibly other bivalves may have some potential for the monitoring of biological responses to organic contamination. This might allow for the development of specific indices of response based on the induction of these enzymes. However, a cautionary note must be added to the effect that additional information is still required on the effects of season, gametogenesis, nutrition and temperature on the components of the detoxication system.

Measurement of specific contaminant responses would complement the general biological stress responses to adverse environmental conditions such as reductions in scope for growth (Bayne et al., 1976, 1979), increases in the concentration ratio of taurine: glycine (Jeffries, 1972; Bayne et al., 1976) and disruption of normal lysosomal functions due to stress induced lysosomal destabilisation (Bayne et al., 1976, 1979; Moore, 1976, 1979, 1980; Moore et al., 1978). Reductions in scope for growth and destabilisation of lysosomes have been observed in mussels experimentally exposed to WAF of crude oil as described above, as well as structural alterations in the digestive cells of the digestive gland tubules (Widdows et al., 1980b). However, these types of stress responses can be induced by a wide range of natural and anthropogenic environmental stressors (Bayne et al., 1976, 1978, 1979) and are by no means limited to the deleterious effects of oil-derived aromatic hydrocarbons. Therefore, any responses which are specifically induced by organic contamination would be useful for the purposes of determining possible causation of deleterious alterations in the general indices of effect, occurring in natural populations.

\section{Implications of xenobiotic metabolism for the mussel}

The presence of mixed function oxygenases in bivalve molluscs implies that reactive electrophilic metabolites such as diolepoxides, in the particular case of aromatic hydrocarbons, could be produced. However, the low levels of activity for enzymic components of the detoxication system suggest that it probably does not play an important part in the removal of organic xenobiotics from the tissues. Nevertheless, diolepoxides of benzo(a)pyrene have high mutagenic and carcinogenic activity (Levin et al., 1978) and it is considered likely that similar metabolites of other environmental hydrocarbons such as chrysenes and dibenzanthracene are also ultimate carcinogens (Jerina et al., 1978). These compounds are carcinogenic at very low concentrations in mammals (Levin et al., 1978) and this could provide an explanation for the apparent prevalence of reported haemocytic neoplasms in mussels (Farley, 1969a; Farley \& Sparks, 1970; Lowe \& Moore, 1978), since the blood cells (haemocytes) would appear to have a higher potential for metabolising organic xenobiotics. However, we still require more information on the tissue distributions of polycylic aromatic hydrocarbons, as well as the tissue concentrations and fate of any metabolites which may be formed before we can clarify this problem of carcinogenic activity in bivalves.

\section{CONCLUSIONS}

The blue mussel, $M$. edulis, does appear to have a limited capacity to metabolise organic xenobiotics. The biological significance of this detoxication system is as yet 
unknown although there is evidence to suggest that the phenomenon of enzymic induction could provide a usable index of response to contamination by certain organic xenobiotics.

Acknowledgements. This work forms part of the experimental ecology programme of the Institute for Marine Environmental Research, a component of the Natural Environment Research Council. It was commissioned in part by the Department of the Environment (Contract No. DGR 480/288). We are grateful to Mrs. P. E. M. Fieth, Mrs. S. V. Mann and Mrs. S. L. Moore for skilled technical assistance and to Dr. J. F. Payne for allowing us to quote his unpublished data. North Sea crude oil was kindly supplied to us by Shell (U.K.) Ltd.

\section{LITERATURE CITED}

Addison, R. F., Zinck, M. E. \& Willis, D. E., 1978. Induction of hepatic mixed-function oxidase (MFO) enzymes in trout (Salvelinus fontinalis) by feeding Aroclor 1254 or 3-methylcholanthrene. Comp. Biochem. Physiol. 61C, 323-325.

Altman, F. P., 1972. Quantitative dehydrogenase histochemistry with special reference to the pentose shunt dehydrogenases. - Prog. Histochem. Cytochem. 4, 225-273.

Barry, M. M. \& Yevich, P. P., 1972. Incidence of gonadal cancer in the quahaug. - Oncology 26, 87-96.

Bayne, B. L., Livingstone, D. R., Moore, M. N. \& Widdows, J., 1976. A cytochemical and a biochemical index of stress in Mytilus edulis L. - Mar. Pollut. Bull. 7, 221-224.

Bayne, B. L., Holland, D. L., Moore, M. N., Lowe, D. M. \& Widdows, J., 1978. Further studies on the effects of stress in the adult on the eggs of Mytilus edulis. - J. mar. biol. Ass. U. K. 58, 825-841.

Bayne, B. L., Moore, M. N., Widdows, J., Livingstone, D. R. \& Salkeld, P. N., 1979. Measurement of the responses of individuals to environmental stress and pollution. - Phil. Trans. R. Soc. (B.) 286, 563-581.

Bend, J. R., James, M. O. \& Dansette, P. M., 1977. In vitro metabolism of xenobiotics in some marine animals. - Ann. N. Y. Acad. Sci. 277, 505-521.

Bresnick, E. \& Yang, H.-Y., 1964. The influence of phenobarbital administration upon the "soluble" NADP-requiring enzymes in liver. - Biochem. Pharmarc. 13, 497-505.

Burns, K. A., 1976. Hydrocarbon metabolism in the intertidal fiddler crab Uca pugnax. - Mar. Biol. $36,5-11$.

Butcher, R. G. \& Altman, F. P., 1973. Studies on the reduction of tetrazolium salts. II. The measurement of the half reduced and fully reduced formazans of neotetrazolium chloride in tissue sections. - Histochemie 37, 351-363.

Carlson, G. P., 1972. Detoxification of foreign organic compounds by the quahaug, Mercenaria mercenaria. - Comp. Biochem. Physiol. 43B, 295-302.

Chayen, J., 1978. Microdensitometry. In: Biochemical mechanisms of liver injury. Ed by T. F. Slater. Acad. Press, London, 259-292.

Conney, A. H. \& Burns, J. J., 1972. Metabolic interactions among environmental chemicals and drugs. - Science, N. Y. 178, 576-586.

Daly, J. W., Jerina, D. M. \& Witkop, B., 1972. Arene oxides and the NIH shift: the metabolism, toxicity and carcinogenicity of aromatic compounds. - Experientia 28, 1129-1149.

Farley, C. A. 1969a. Sarcomatoid proliferative disease in a wild population of blue mussels (Mytilus edulis). - J. natn. Cancer Inst. 43, 509-516.

Farley, C. A., 1969b. Probable neoplastic disease of the hematopoetic system in oysters, Crassostrea virginica and Crassostrea gigas. - Natn. Cancer Inst. Monogr. 31, 541-555.

Farley, C. A. \& Sparks, A. K., 1970. Proliferative diseases of hemocytes, endothelial cells, and connective tissue cells in molluscs. - Bibl. Haematol. 36, 610-617.

Gee, S. J., Krieger, R. I., Lim, L. O. \& Wellings, S. R., 1979. Disposition processes in mussels, Mytilus californianus. - Toxic. app. Pharmac. (In press.)

Gillette, J. R., Hinson, J. A. \& Andrews, L. S., 1978. Pharmacokinetic aspects of the formation and inactivation of chemically reactive metabolites. In: Polycyclic hydrocarbons and cancer. Ed. by H. V. Gelboin \& P. O. P. Ts'o. Acad. Press, London 1, 375-398. 
Groves, W. E., Davies, F. C. \& Sells, B. H., 1968. Spectrophotometric determination of microgram quantities of protein without nucleic acid interference. - Ann. Biochem. 22, 195-210.

Hardonk, M. J. and Koudstaal, J., 1976. Enzyme histochemistry as a link between biochemistry and morphology. - Prog. Histochem. Coytochem, 8 (2), 1-68.

Head, E. J. H., 1979. NADP-dependent isocitrate dehydrogenase in marine bivalve molluscs. Ph. D. thesis, University of Wales, $125 \mathrm{pp}$.

Hori, S. H. \& Takahashi, T., 1974. Phenobarbitol-induced increase of hexose-6-phosphate dehydrogenase activity. - Biochem. biophys. Res. Commun. 61, 1064-1070.

Jeffries, H. P., 1972. A stress syndrome in the hard clam, Mercenaria mercenaria. - J. Invertebr. Pathol. 20, 242-287.

Jerina, D. M. \& Daly, J. W., 1974. Arene oxides: a new aspect of drug metabolism. - Science, N. Y. $185,573-582$.

Jerina, D. M., Yagi, H., Lehr, R. E., Thakker, D. R., Schaefer-Ridder, M., Karle, J. M., Levin, W., Wood, A. W., Chang, R. L. \& Conney, A. H., 1978. The bay-region theory of carcinogenesis by polycyclic aromatic hydrocarbons. In: Polycyclic hydrocarbons and cancer. Ed. by H. V. Gelboin \& P. O. P. Ts'o. Acad. Press, London 1, 173-188.

Jollow, D. J., Mitchell, J. R, Zampaglione, N. \& Gillette, J. R., 1974. Bromobenzene induced liver necrosis. Protective role of glutathione and evidence for 3,4 -bromobenzene oxide as the hepatotoxic metabolite. - Pharmacology 11, 151-169.

Khan, M. A. W., Kamal, A., Wolin, R. J. \& Runnels, J., 1972. In vivo and in vitro epoxidation of aldrin by aquatic food chain organisms. - Bull. environ. Contam. Toxicol. 8, 219-228.

Khandwala, A. S. \& Kaspar, C. B., 1973. Preferential induction of aryl hydroxylase activity in rat liver nuclear envelope by 3-methylcholanthrene. - Biochem. biophys. Res. Commun. 54, 1241.

Kimura, K., Endou, H., Sudo, J. \& Saki, F., 1979. Glucose dehydrogenase (hexose-6-phosphate dehydrogenase) and the microsomal electron transport system. - J. Biochem. 85, 319-326.

Koudstaal, J. and Hardonk, M. J., 1969. Histochemical demonstration of enzymes related to NADPH-dependent hydroxylating systems in rat liver after phenobarbital treatment. - Histochemie $23,68-77$.

Koudstaal, J. \& Hardonk, M. J., 1972. Relations between biochemically determined hydroxylations and some enzyme-histochemical reactions in rat liver after phenobarbital and methylcholanthrene treatment. - Acta histochem. (Suppl.) 12, 279-282.

Krieger, R. I. \& Wilkinson, C. F., 1969. Microsomal mixed-function oxidases in insects. I. Localisation and properties of an enzyme system effecting aldrin epoxidation in larvae of the southern army worm (Prodenia eridania). - Biochem. Pharmac. 18, 1403-1415.

Krieger, R. I., Gee, S. J., Lim, O. L., Ross, J. H. \& Wilson, A., 1979. Disposition of toxic substances in mussels (Mytilus californianus): preliminary metabolic and histologic studies. In: Pesticide and xenobiotic metabolism in aquatic organisms. Ed. by M. A. Q. Khan, J. J. Lech \& J. J. Menn. American Chemical Society, Washington, D. C., 259-277.

Kuroki, T., Huberman, E., Marquardt, H., Selkirk, J. K., Heidelberger, C., Grover, P. L. \& Sims, P. 1971-1972. Binding of K-region epoxides and other derivatives of benz(a)anthracene and dibenz(a,h)-anthracene to DNA, RNA, and proteins of transformable cells. - Chem.-biol. Interact. 4, 389-397.

Lee, R. F., Sauerheber, R. \& Bensen, A. A., 1972. Petroleum hydrocarbons: uptake and discharge by the marine mussel Mytilus edulis. - Science, N. Y. 177, 344-346.

Lesko, S. A., Lorentzen, R. J. \& Ts'o, P. O. P., 1978. Benzo(a)pyrene metabolism: one-electron pathways and the role of nuclear enzymes. In: Polycyclic hydrocarbons and cancer. Ed. by H. V. Gelboin \& P. O. P. Ts'o. Acad. Press, London 1, 261-269.

Levin, W., Wood, A. W., Wislocki, P. G., Chang, R. L., Kapitulnick, J., Mah, H. D., Yagi, H., Jerina, D. M. \& Conney, A. H., 1978, Mutagenicity and carcinogenicity of benzo(a)pyrene and benzo(a)pyrene derivations. In: Polycyclic hydrocarbons and cancer. Ed. by H. V. Gelboin \& P. O. P. Ts'o. Acad. Press, London 1, 189-202.

Lindner, E. \& Beyhl, F. E., 1978. Induction of microsomal drug-metabolizing enzymes caused by hexobarbital. - Experientia 34, 226-227.

Livingstone, D. R., 1980. Seasonal variation in glucose-6-phosphate dehydrogenase from the mantle and digestive gland of Mytilus edulis L.: induction of enzyme activities as a mechanism for the seasonal control of metabolism in marine invertebrates (in prep.). 
Lowe, D. M. \& Moore, M. N., 1978. Cytology and quantitative cytochemistry of a proliferative atypical hemocytic condition in Mytilus edulis (Bivalvia, Mollusca). - J. natn. Cancer Inst. 60, 1455-1459.

Lowry, O. H., Rosebrough, N. J., Farr, A. L. \& Randall, R. J., 1951. Protein measurement with the Folin phenol reagent. - J. biol. Chem. 193, 265-275.

Mix, M., 1975. Proliferative characteristics of atypical cells in native oysters (Ostrea lurida) from Yaquina Bay, Oregon. - J. Invertebr. Pathol. 26, 289-298.

Mix, M. C., Pribble, H. J., Riley, R. T. \& Tomasovic, S. P., 1977. Neoplastic disease in bivalve mollusks from Oregon estuaries with emphasis on research in proliferative disorders in Yaquina Bay oysters. - Ann. N. Y. Acad. Sci. 298, 356-373.

Moore, M. N., 1976. Cytochemical demonstration of latency of lysosomal hydrolases in digestive cells of the common mussel, Mytilus edulis, and changes induced by thermal stress. - Cell. Tiss. Res. $175,279-287$.

Moore, M. N., 1979. Cellular responses to polycyclic aromatic hydrocarbons and phenobarbital in Mytilus edulis. - Mar. Environ. Res. 2, 255-263.

Moore, M. N., 1980. Cytochemical determination of cellular responses to environmental stressors in marine organisms. - Rapp. P.-v. Reun. Cons. int. Explor. Mer. (In press.)

Moore, M. N., Lowe, D. M. \& Fieth, P. E. M., 1978. Lysosomal responses to experimentally injected anthracene in the digestive cells of Mytilus edulis. - Mar. Biol. 48, 297-302.

Payne, J. F., 1977. Mixed function oxidases in marine organisms in relation to petroleum hydrocarbon metabolism and detection. - Mar. Pollut. Bull. 8, 112-116.

Payne, J. F. \& Penrose, W. R., 1975. Induction of aryl hydrocarbon (benzo(a)pyrene) hydroxylase in fish by petroleum. - Bull. environ. Contam. Toxicol. 14, 112-116.

Richards, T. C., 1973. Histochemical changes in developing mouse liver after administration of phenobarbital. - Am. J. Anat. 138, 449-464.

Silva-Pando, M., Carrion-Angosto, A. \& Ruiz-Amil, M., 1978. Glucosa-6-fosfato dehidrogenasa de hepatopancreas de mejillon. - Rev. esp. Fisiol. 34, 1-8.

Sims, P. \& Grover, P. L., 1974. Epoxides in polycyclic aromatic hydrocarbon metabolism and carcinogenesis. - Adv. Cancer Res. 20, 165-274.

Stegeman, J. J., 1980. Mixed-function oxygenase studies in monitoring for effects of organic pollution. - Rapp. P.-v. Réun. Cons. int. Explor. Mer. (In press.)

Stegeman, J. J. \& Klotz, A. V., 1979. A possible role for microsomal hexose-6-phosphate dehydrogenase in microsomal electron transport and mixed-function oxygenase activity. - Biochem. biophys. Res. Commun. 87, 410-415.

Stegeman, J. J. \& Sabo, D. J., 1976. Aspects of the effects of petroleum hydrocarbons on intermediary metabolism and xenobiotic metabolism in marine fish. In: Sources, effects and sinks of hydrocarbons in the aquatic environment. Am. Inst. Biol. Sci., Arlington, Virginia, 423-436.

Trautman, T. D., Gee, S. J., Krieger, R. I. \& Thongsinthusak, T., 1979. Sensitive radioassay of microsomal o-demethylation of ${ }^{14} \mathrm{CH}_{3} \mathrm{O}$ - or $\mathrm{C}^{3} \mathrm{H}_{3} \mathrm{O}$-p-nitroanisole for comparative studies. Comp. Biochem. Physiol. 63C, 333-339.

Vandermeulen, J. H. \& Penrose, W. R., 1978. Absence of aryl hydrocarbon hydroxylase (AHH) in three marine bivalves. - J. Fish. Res. Bd Can. 35, 643-647.

Widdows, J., Bayne, B. L., Donkin, P., Livingstone, D. R., Lowe, D. M., Moore, M. N. \& Salkeld, P. N., $1980 \mathrm{a}$. Measurement of the responses of mussels to environmental stress and pollution in Sullom Voe: a baseline study. - Trans. R. Soc. Edinb. (In press.)

Widdows, J., Bakke, T., Bayne, B. L., Donkin, P., Livingstone, D. R., Lowe, D. M., Moore, M. N., Fieth, P. E. M., Mann, S. V. \& Moore, S. L., 1980b. General responses to stress in Mytilus edulis following exposure to the water accomodated fraction of North Sea oil. (In prep.)

Willis, D. E. \& Addison, R. F., 1974. Hydroxylation of biphenyl in vitro by tissue preparation of some marine organisms. - Comp. gen. Pharmac. 5, 77-81. 